\title{
高速応答性を有する気体用層流型流量計の特性解析 †
}

\author{
舩木 達 也*・川嶋 健 嗣* 香 川 利 春* \\ Characteristic Analysis of Laminar Flow Meter for Gases with High Speed Response ${ }^{\dagger}$ \\ Tatsuya Funaki*, Kenji Kawashima* and Toshiharu Kagawa*

\begin{abstract}
The unsteady flow rate measurement of gases is very important in various industrial fields. In this paper, we examined theoretically and experimentally the static and dynamic characteristics of a laminar flow meter for gases. We confirmed the flow meter can measure oscillatory flow up to $50[\mathrm{~Hz}]$ and the laminar flow meter has phase-lead characteristic theoretically and experimentally. The laminar flow meter with high speed response which is calibrated dynamically can be used for precise pressure control circuits.
\end{abstract}

Key Words: flow measurement, oscillatory flow, laminar flow meter, dynamic characteristics

\section{1. 緒言}

気体の流量計測技術は, 非常に多様な測定原理を活用して さまざまな分野で利用されている，最近では半導体製造装置 や燃料電池の流量管理, エンジンや人工呼吸器の流量制御 などにおいて，定常のみらず，非定常流量計測が非常に重要 となっている。そこで，近年の MEMS 技術を用いた熱式流 量センサが数多く開発され, 小型化の利点を活かし, 非定常 流量計測への適用が行なわれている。また，同じくMEMS 技術を用いて製作された静電容量式をはじめとする高精度, 高分解能の差圧センサを利用した差圧式流量計も用いられ ている.

しかしながら, 気体の密度は温度と圧力の関数となること から, 非定常流量計測はきわめて困難であり, 気体用流量計 の動特性を試験する方法は確立されておらず ISO などでの 規定もなされていない. よって，市販の流量計の応答性は流 量をステップ的に変化させたときの応答速度を計測するのみ で，ほとんどが $10[\mathrm{~Hz}]$ 以下の応答速度である．しかし，半 導体技術の高度化・集積化に伴い, 半導体チップの着座確認 や半導体露光装置用の空気ばね式除振台の流量管理などで は, 小流量域において, $50[\mathrm{~Hz}]$ 程度の高速応答可能な流量 計が必要となっている.

一般に微小および小流量計測を行なう際には, 差圧式流量 計の中でも層流型流量計がよく用いられる。この流量計は， 絞り流量計の代表例であるオリフィス流量計とは異なり, 生

† SICE Annual Conference 2003 in Fukui で発表 (2003・8)

* 東京工業大学 精密工学研究所

* Tokyo Institute of Technology, Precision and Intelligence Laboratory

(Received April 6, 2004)

(Revised August 5, 2004)
じる圧力差と測定流量との間に線形関係を有している。この ため，広いレンジアビリティの確保が容易で，かつ動特性が 良いことが知られている1)。しかしながら，実験による動特 性検証はほとんど行なわれておらず，理論的な説明もウォー

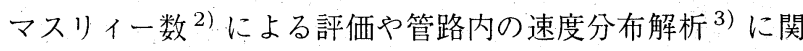
しては多くの研究がなされているものの流量計測への展開 はなされていない.

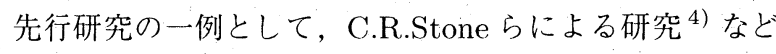
があるが, 理論式の導出は行なわれているものの, 時々刻々 の流量応答波形の提示はなされていない。また，内燃機関の 間欠気流測定 ${ }^{5)}$ の研究もあるが，最大でも $30[\mathrm{~Hz}]$ 程度まで の流れの評価しか行なわれていない.

一方，流量計の動特性を検証する手法には，著者らが提案 している等温化圧力容器を用いた非定常流量発生装置 ${ }^{6)}$ が ある。これを用いれば，標準不確かさ ${ }^{7)} 5 \%$ (F.S) で任意の 振動流を発生可能であり，実際に $100[\mathrm{~Hz}]$ 程度までの動特性 評価の有用性を確認している.

そこで本研究では，大気圧の乾燥空気を測定対象として， 高速応答計測を実現すべく差圧を利用した層流型流量計に 着目し，その特性を明らかにした上で設計製作を行ない，高 速応答の実現を目的とする。特に，動特性に関しては非定常 流量発生装置を用いた検証と，ナビエ・ストークス方程式の 非定常項の検討を行ない, 理論と実験の両面からの結果を踏 まえて，層流型流量計の動特性を評価する。

\section{記号表}

$\begin{array}{rlr}b & : \text { 振幅比 } & {[-]} \\ d & : \text { 細管直径 } & {[\mathrm{m}]} \\ D & : \text { 流路直径 } & {[\mathrm{m}]}\end{array}$




\begin{tabular}{|c|c|c|}
\hline$f$ & : 周波数 & {$[\mathrm{Hz}]$} \\
\hline$L$ & : 細管長 & {$[\mathrm{m}]$} \\
\hline$L_{i}$ & : 助走距離 & {$[\mathrm{m}]$} \\
\hline$n$ & : 細管本数 & {$[-]$} \\
\hline$P$ & : 圧力 & {$[\mathrm{Pa}]$} \\
\hline$Q$ & ：標準状態体積流量 & {$\left[\mathrm{m}^{3} / \mathrm{s}\right]$} \\
\hline$Q_{a}$ & : 振動流の振幅体積流量 (標準状態) & {$\left[\mathrm{m}^{3} / \mathrm{s}\right]$} \\
\hline$Q_{m}$ & : 振動流の平均体積流量 (標準状態) & {$\left[\mathrm{m}^{3} / \mathrm{s}\right]$} \\
\hline$Q_{s}$ & : 細管 1 本あたりの体積流量 (標準状態) & {$\left[\mathrm{m}^{3} / \mathrm{s}\right]$} \\
\hline$r$ & 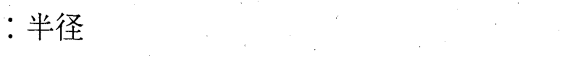 & {$[\mathrm{m}]$} \\
\hline$R$ & : 細管半径 & {$[\mathrm{m}]$} \\
\hline$R e$ & : レイノルズ数 & {$[-]$} \\
\hline$t$ & ：時間 & {$[\mathrm{s}]$} \\
\hline$u$ & : 速度 & {$[\mathrm{m} / \mathrm{s}]$} \\
\hline$u_{m}$ & : 平均速度 & {$[\mathrm{m} / \mathrm{s}]$} \\
\hline$u_{a}$ & : 振幅速度 & {$[\mathrm{m} / \mathrm{s}]$} \\
\hline$W_{o}$ & ：ウォーマスリィー数 $(=d \sqrt{\omega / \nu})$ & {$[-]$} \\
\hline$\Delta P$ & ：差圧 & {$[\mathrm{Pa}]$} \\
\hline$\Delta P_{1}$ & : ハーゲン・ポアズイユ流れに伴う压力損失 & {$[\mathrm{Pa}]$} \\
\hline$\Delta P_{2}$ & $: \Delta P_{1}$ 以外に生じる圧力損失 & {$[\mathrm{Pa}]$} \\
\hline$\xi$ & ：損失係数 & {$[-]$} \\
\hline$\rho$ & : 空気の密度 & {$\left[\mathrm{kg} / \mathrm{m}^{3}\right]$} \\
\hline$\mu$ & : 粘度 & {$\left[\mathrm{N} \cdot \mathrm{s} / \mathrm{m}^{2}\right]$} \\
\hline$\nu$ & ：動粘度 & {$\left[\mathrm{m}^{2} / \mathrm{s}\right]$} \\
\hline$\omega$ & : 角振動数 & {$[\mathrm{rad} / \mathrm{s}]$} \\
\hline
\end{tabular}

\section{2. 層流型流量計}

層流型流量計は多数の細管などを挿入して層流エレメン トを構成し, その前後圧力差から流量を計測するものであ る. 今, 円管内の流動は, 円筒座標系での非圧縮性流体のナ ビエ・ストークス方程式である (1) 式で記述できる.

$$
\frac{\partial u}{\partial t}+u \frac{\partial u}{\partial x}=-\frac{1}{\rho} \frac{\partial P}{\partial x}+\nu\left(\frac{\partial^{2} u}{\partial r^{2}}+\frac{1}{r} \frac{\partial u}{\partial r}\right)
$$

現在までに，円管内の非定常流動応答解析の研究報告例とし ては, 円管内助走区間における振動流の解析 ${ }^{8)}$, 管路の過渡 応答解析 ${ }^{9), 10)}$ や非定常流量計測への適用 ${ }^{11)}$ など数多くあ る.しかし, 厳密解の導出が困難である点や適用条件などに 問題が残っている.したがって, より簡便で, かつ妥当な動 特性評価が可能ならば, 流量計測技術への貢献度は高いと考 えられる。そこで, 流机は定常, かつ(1) 式の第 2 項である 対流項は微小であるので無視し，さらに非定常な変化がな いとして非定常項も無視する．得られた式を半径方向に積 分し，円管における流れが十分発達した層流であるならば， '円管内の速度分布は次式で表わすことができる。

$$
u=-\frac{1}{4 \mu} \frac{d P}{d x}\left(\frac{d^{2}}{4}-r^{2}\right)
$$

このような円管内の流れはハーゲン・ポアズイユ流れ ${ }^{11)}$ と 呼ばれ，円管内径 $d$, 長さ $L$ の細管一本を通過する体積流 量 $Q_{s}$ は, (2) 式を積分して次式となる.

$$
Q_{s}=-\frac{\pi d^{4}}{128 \mu} \frac{d P}{d x}=\frac{\pi d^{4} \Delta P}{128 \mu L}
$$

なお, 層流型流量計全体では, $n$ 本の細管から構成されてい るので (3) 式を $n$ 倍することで体積流量が求められる.

以上より，層流型流量計は体積流量が圧力差に比例する特 性を有している. なお, 大気圧下の空気の密度を $\rho_{a}$, 大気 圧を $P_{a}$, 層流形流量計が設置されるライン圧を $P_{c}$ とすれ ば，質量流量 $G$ は次式で求めることができる.

$$
G=\rho_{a} \frac{P_{c}}{P_{a}} Q
$$

3. 設計

\section{1 手順}

今回製作した層流形流量計の設計方法についてまとめる. はじめに, 測定対象を大気圧の乾燥空気とし, 本流量計の測 定最大流量を $16.7 \times 10^{-4}\left[\mathrm{~m}^{3} / \mathrm{s}\right]$ とする. 一方, 動特性を 考慮し, 層流エレメントを構成する細管は外径 $0.8[\mathrm{~mm}]$, 内 径 $0.6[\mathrm{~mm}]$ とした。このとき細管長に応じて, 本流量計で 生じる圧力差を調節できる。一般に, 各種配管系に流量計を 設置した場合, 流量計自身による損失は極力小さくしたい. しかしながら，極端に損失を小さくしてしまうと，圧力差が 測定器の分解能に埋もれてしまい正確な計測を実施できな い. そこで, 近年の半導体製造技術を応用して製作された微 差圧センサを活用することを考え, その測定範囲から最大 $400[\mathrm{~Pa}]$ とした。この結果，細管長は $50[\mathrm{~mm}]$ とした.

つぎに, 層流型流量計の応答性能を評価するため, 層流工 レメントを構成する細管一本に着目し, その静特性および動 特性を評価した，静特性では，ハーゲン・ポアズイユ流れで 想定される以外の各圧力損失による影響を調べた。さらに動 特性に関しては, 振動流の応答特性を, ナビエ・ストークス 方程式とウォーマスリー数の観点から検討し設計へ反映さ せた。

\section{2 助走区間の影響}

一般に層流型流量計は, 測定流量と差圧との間に線形関 係を有している.しかし厳密にはこの圧力損失以外も存在 する。今，マッハ数が 0.3 以下の領域で使用することを考え ているため，流体の圧縮性はほぼ無視できる，流量計前後の 圧力差 $\Delta P$ は，層流エレメントを構成している細管長 $L$ に わたりハーゲン・ポアズイユ流れと仮定した場合の圧力降下 $\Delta P_{1}$ と，エレメント入口・出口部における圧力降下および 入口助走区間における損失などによる $\Delta P_{2}$ との総和として 表わされる.つまり，

$$
\begin{aligned}
\Delta P_{1} & =\lambda \frac{L}{d} \cdot \frac{\rho u^{2}}{2} \\
\Delta P_{2} & =\xi \frac{\rho u^{2}}{2}
\end{aligned}
$$

となる.ここで， $\xi$ は損失係数を示す，また，層流の場合の 管摩擦係数は, $\lambda=64 / R e^{11)}$ で与えられるので, 細管一本 あたりの総圧力損失を整理すると， 


$$
\Delta P=\Delta P_{1}+\Delta P_{2}=32 \mu\left(\frac{L}{d^{2}}\right) u+\xi \frac{\rho u^{2}}{2}
$$

となる。しかしながら，前述したとおり，層流形流量計では ハーゲン・ポアズイユ流れを仮定した圧力損失以外に助走区 間や入口出口での損失を考慮しなければならない.したがっ て，厳密な線形関係を構築できる範囲は，後者の圧力損失 が前者の損失に対して相対的に小さい必要がある.そこで， $\Delta P_{1}$ と $\Delta P_{2}$ との比を考えると，(5) 式と (6) 式および層流 時の管摩擦係数を考慮すれば次式が成立する.

$$
\frac{\Delta P_{2}}{\Delta P_{1}}=\frac{\xi}{64}\left(\frac{d}{L}\right) R e=\frac{\xi}{64} \frac{\rho u}{\mu}\left(\frac{d^{2}}{L}\right)
$$

この (8) 式において, $\Delta P_{1}$ と $\Delta P_{2}$ の比を小さくすること で，高い線形性を補償できる。本研究では，ハーゲン・ポア ズイユ流れに伴う圧力損失以外の割合を $5 \%$ 以下とした。こ の結果,

$$
\left|\frac{\Delta P_{2}}{\Delta P_{1}}\right| \leq 0.05
$$

の条件を得る。ここで，層流状態における助走区間の損失係 数は，一般に細管入出部がベルマウスならば $\xi \approx 2.3^{11)}$ で あることを踏まえ，細管の直径 $d$ とすると，必要な細管長 $L$ は次式で求められる.

$$
L \geq \frac{R e}{3.2} \xi d
$$

本実験では試作した流量計の測定最大流量を $400[\mathrm{~Pa}]$ で $16.7 \times 10^{-4}\left[\mathrm{~m}^{3} / \mathrm{s}\right]$ と想定したので，細管内では最大 $R e=121.8$ となり必要細管長は $52.5[\mathrm{~mm}]$ と求められた. これは，先に設定した $50[\mathrm{~mm}]$ の細管長では若干不足するも ののほぼ問題ないことが確認できた。また，細管の助走区間 距離 ${ }^{11)}$ は次式で表わされる。

$$
L_{i}=0.058 \times R e \times d
$$

結果, 助走距離は約 $4.2[\mathrm{~mm}]$ で細管長全体の約 $8 \%$ に収まる ことがわかった。

\section{3 非定常項の考察}

本節では，層流型流量計における動特性への影響因子とし て非定常項に着目し検討した。はじめに，円筒座標系におけ る非圧縮性流体のナビエ・ストークス方程式について，影響 の小さい対流項を無視して (1) 式を整理すると次式となる。

$$
\frac{\partial u}{\partial t}=-\frac{1}{\rho} \frac{\partial P}{\partial x}+\nu\left(\frac{\partial^{2} u}{\partial r^{2}}+\frac{1}{r} \frac{\partial u}{\partial r}\right)
$$

つぎに，(8) 式を半径方向に積分し $r=0$ で $\partial u / \partial r=0$ の 境界条件を用いて整理すると次式となる。

$$
\frac{\partial u}{\partial r}=\frac{r}{2 \mu} \frac{\partial P}{\partial x}+\frac{r}{2 \nu} \frac{\partial u}{\partial t}
$$

この式を $u$ と $r$ の変数分離型として,$r=R$ で $u=0$ の境 界条件を用いて積分し整理すると, 円管内の流速 $u$ は次式 で表現できる.

$$
u=\frac{1}{4 \mu} \frac{\partial P}{\partial x}\left(r^{2}-R^{2}\right)+\frac{1}{4 \nu} \frac{\partial u}{\partial t}\left(r^{2}-R^{2}\right)
$$

さらに半径方向に積分し, 体積流量 $Q$ は次式となる.

$$
Q=\frac{\pi R^{4}}{8 \mu}\left(-\frac{\partial P}{\partial x}\right)-\frac{\pi R^{4}}{8 \nu} \frac{\partial u}{\partial t}
$$

一般に，圧力勾配が生じた際に流動現象が確認されるた め，理論的な解析では，初期条件として圧力を与えることが 多い.しかしながら，本研究では等温化圧力容器を用いた非 定常流量発生装置を用いて，層流型流量計の動特性評価を行 なう観点から，発生流量もしくはその際の流速を与えた場合 に，結果としてどのような圧力差を生じるかが問題となる。 つまり，層流型流量計での測定值は圧力差であり，与えるも のは流量である.そこで，(15) 式を圧力差に関して，整理 すると次式となる。

$$
\frac{\pi R^{4}}{8 \mu}\left(-\frac{\partial P}{\partial x}\right)=Q-\frac{\pi R^{4}}{8 \nu} \frac{\partial u}{\partial t}
$$

ここで，振動流 $Q$ を $Q=Q_{m}+Q_{a} \sin (\omega t)$ として 与えると，流速 $u$ は流路断面全体均一であるとして， $u=u_{m}\{1+b \sin (\omega t)\}$ となる.ただし, $b=u_{a} / u_{m}$ で ある.これを(16) 式に代入し， ウォーマスリィー数 $W_{o}^{2), 4)}$ を用いて整理すると，

$$
Q=\pi R^{2} u_{m}\left\{1+b \sqrt{1+\frac{W_{o}^{4}}{1024}} \sin (\omega t+\phi)\right\}
$$

と求まる。ここで，位相角は $\phi=\tan ^{-1}\left(W_{o}^{2} / 32\right)$ となる。 また，このウォーマスリィー数は周波数と動粘度の比を表わ す無次元数で，次式のように定義される.

$$
W_{o}=2 R \sqrt{\frac{\omega}{\nu}}=d \sqrt{\frac{\omega}{\nu}}=d \sqrt{\frac{\rho \omega}{\mu}}
$$

この結果, 非定常流量発生装置からの振動流が層流型流量 計を通過した場合，流量測定値は位相進みとなる。これは， 一定の圧力勾配時に生じる流量の振幅が，高周波になるほど 小さくなり，位相遅れとなること 2) 4) と視点が異なるだけ の同一事象である。したがって，(17) 式より周波数が高く なると，流量ゲインは若干大きく，かつ位相進みとなる.

つぎに, ウォーマスリイー数を用いた動特性の具体的な 評価を試みる。その導出過程より，圧力勾配が与えられた 場合における流量応答特性を示す指標がウォーマスリィー 数である。そこで本研究では，前述の留意事項を踏まえ検 討を行なった。一般に，この $W_{o}$ が 1 程度であれば，応答 性能への影響はほとんどない2),4)。この場合，振動流の周 波数は $7[\mathrm{~Hz}]$ に相当する。また，30[Hz] 程度の振動流に対 しては， $W_{0}=2.1$ となり，ゲイン上昇や位相進みとなる. さらに，ゲインが $\sqrt{2}$ 倍で $45^{\circ}\left[^{\circ}\right]$ の位相進みとなるウォーマ スリィー数は約 $2.5^{4)}$ となり，周波数では $40[\mathrm{~Hz}]$ に相当す る。言い換えれば, 本流量計では $30[\mathrm{~Hz}]$ 程度からゲインの 上昇および位相進みの傾向を示すことが予想される。さら に, $40[\mathrm{~Hz}]$ 以上の振動流では追従性の補償が困難となる可 能性がわかった。この結果より，層流型流量計はその動特性 において，ウォーマスリィー数の観点から約 $40[\mathrm{~Hz}]$ 程度の 動特性を有しているという結論を得た。

\section{4 仕様}

以上を踏まえ，設計：製作した層流型流量計の概略図を Fig. 1 に示す．多数の細管を詰めた層流エレメント前後に 導圧孔を設け，この二つの圧力差から流量を測定する。この 


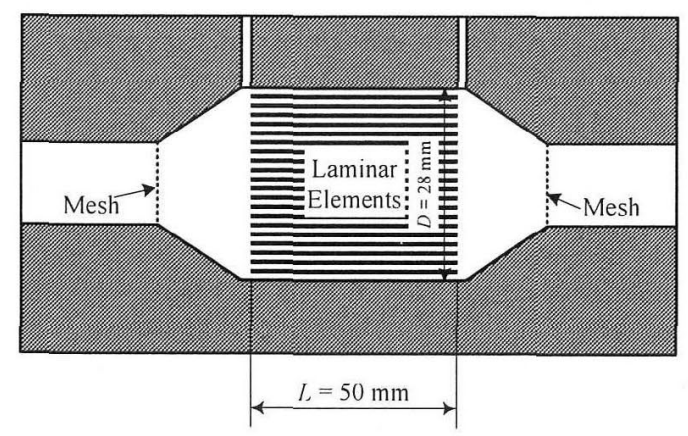

Fig. 1 Laminar flow meter

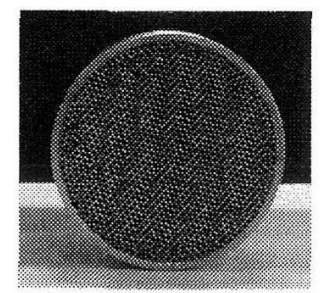

Fig. 2 Laminar elements

層流エレメント (Fig. 2 参照) の直径は $28[\mathrm{~mm}]$, 細管長は $50[\mathrm{~mm}]$ とした。また細管は, 外径 $0.8[\mathrm{~mm}]$, 内径 $0.6[\mathrm{~mm}]$ のものを用い, 入口と出口部分はベルマウス加工を施し余分 な損失を生じないようにした，本実験で使用した層流形流量 計の断面では，理想的には 1225 本分の細管を詰めることが できるが，隙間および詰め方の関係上，実際は約 1100 本の 細管を詰めた状態となった。なお，層流エレメントの上流側 には拡大部，下流側には縮小部を設け，その上流および下流 側には\#100の金網メッシュを配した：また，導圧孔から差 圧センサまでの距離は極力短くするようにした。

\section{4. 実験手 法}

\section{1 静特性}

今回製作した層流形流量計の静特性測定に用いた実験装置 をFig. 3 に示す. 作動流体は大気圧の乾燥空気とした。圧 縮空気供給源より減圧弁を通して任意の圧力に減圧し, 速 度調節弁へと供給して供試流量計への流量を調節した。速 度調節弁の下流側には, 供試流量計を配し，さらに下流側 には基準流量計として, $3.3 \times 10^{-4}\left[\mathrm{~m}^{3} / \mathrm{s}\right]$ 以上の流量域で は標準不確かさ $0.3 \%$ (F.S) の乾式ガスメー夕を, それ以下 の流量域では標準不確かさ $0.15 \%$ (F.S) の湿式ガスメー夕を 用いた。また供試流量計で生じた圧力差は, 最大測定範囲 $500[\mathrm{~Pa}]$, 標潗不確かさ $1 \%$ (F.S) の差圧伝送器を用いた。

\section{2 動特性}

動特性の検証には, Fig. 4 に示す等温化圧力容器を用いた 非定常流量発生装置 ${ }^{6)}$ を使用した。この装置では, 等温化圧 力容器内の圧力測定結果を用い, 所定の圧力変動となるよう にサーボ弁の開度を調節する制御信号を PCによる計算で求 めてから与え, 標準不確かさ $5 \%$ (F.S) で流量および周波数

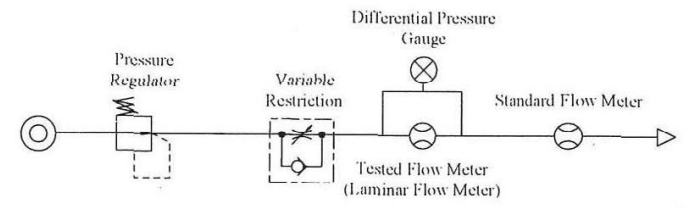

Fig. 3 Experimental apparatus for static characteristic measurement

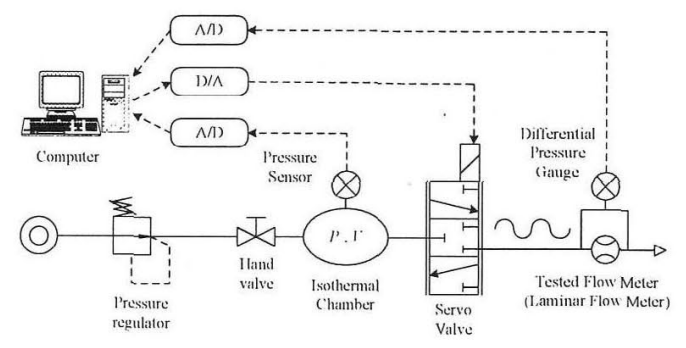

Fig. 4 Experimental apparatus for dynamic characteristic measurement

を調整した任意の振動流を発生可能なことを確認している. 作動流体は, 大気圧の乾燥空気とし, 発生振動流は, 設計し た層流型流量計の測定範囲の中央である平均流量 $8.3 \times 10^{-4}$ $\left[\mathrm{m}^{3} / \mathrm{s}\right]$, 振幅流量 $5.0 \times 10^{-4}\left[\mathrm{~m}^{3} / \mathrm{s}\right]$, 振幅比 $b=0.6$ とし た. なお，発生装置の制御ならびに測定值のデータ取得では, $1[\mathrm{~Hz}]$ の振動流では $1[\mathrm{~ms}], 5[\mathrm{~Hz}]$ から $20[\mathrm{~Hz}]$ では $0.5[\mathrm{~ms}]$, $30[\mathrm{~Hz}]$ 以上では $0.2[\mathrm{~ms}]$ のサンプリング洔間とした。また, 本流量計の測定值は止力差であることから, 静特性の結果を もとに流量換算を行なった。さらに, 等温化压力容器を用い た非定常流量発生装置は, 圧力センサの分解能から, 発生さ せる振動流の周波数に応じて容器の大きさを变更した ${ }^{6)}$. 具 休的には, $10[\mathrm{~Hz}]$ 以下では $1.413 \times 10^{-3}\left[\mathrm{~m}^{3}\right]$, 以降 $40[\mathrm{~Hz}]$ までは $0.466 \times 10^{-3}\left[\mathrm{~m}^{3}\right], 60[\mathrm{~Hz}]$ までは $0.35 \times 10^{-3}\left[\mathrm{~m}^{3}\right]$, $100[\mathrm{~Hz}]$ までは $0.186 \times 10^{-3}\left[\mathrm{~m}^{3}\right]$ とし, 高周波数なほど小 さい等温化圧力容器を使用した，なお差圧測定には, センサ 自体の動特性を考慮して, 固有振動数 $1.7[\mathrm{kHz}]$, 標準不確 かさ $0.5 \%$ (F.S) のひずみゲージ式差圧変換器 2 台を, 高圧 側, 低厈側のそれぞれに配置し, 両方とも低圧側を大気解放 としたゲージ压計として利用した。センサからの出力信号 は, パソコン内で処理し, 圧力差を算出の上, 流量換算を行 なった。

\section{5. 実 験 結 果}

\section{1 静特性}

静特性の実験結果を Fig. 5 に示す.この図より, 測定し た圧力差 $400[\mathrm{~Pa}]$ まで本流量計が高い線形性を有している ことが確認できた。また，図中の実線は (3) 式より細管木数 を考慮して得られた計算結果を示しているが，本流量計が 理論式とよく一致していることもわかる，つぎに，本流量計 の線形性を評価するために，ハーゲン・ポアズイユ流れで 


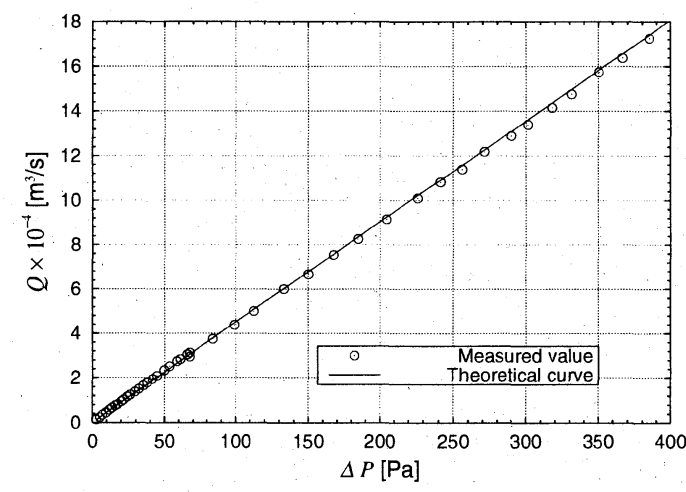

Fig. 5 Static characteristic of tested laminar flow meter

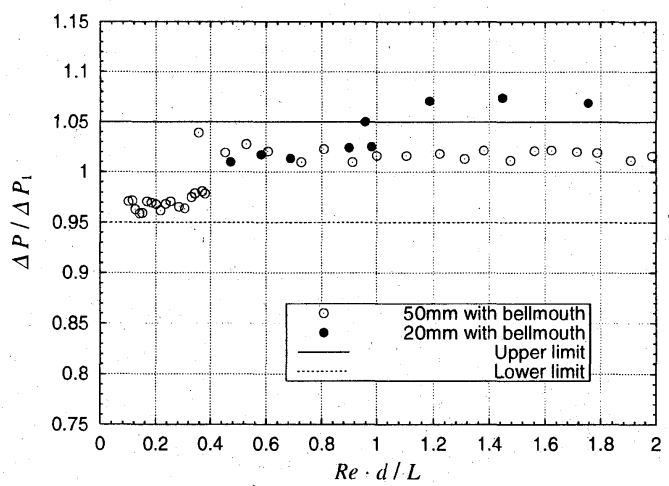

Fig. 6 Linearity of tested laminar flow meter

の圧力損失 $\Delta P_{1}$ と全圧力損失 $\Delta P\left(=\Delta P_{1}+\Delta P_{2}\right)$ の比を 求め Fig. 6 に示す.この結果, 今回想定した流量測定範囲 内 $(R e \cdot d / L$ が 1.46 以下) において，(9) 式の条件以内に 入っていることが確認できた。 な扔，非常に流量が少ない場 合において，想定した圧力損失よりも少ない傾向を示した。 これは使用した差圧伝送器自体の測定誤差や流路構造挹よ び流れの状態による影響などが考えられる，以上の結果か ら，本流量計がレシジアビリティは 20:1を確保できている ことを確認した。参考までに細管長 $20[\mathrm{~mm}]$ の測定結果も 表記したが，この場合，助走区間距離が細管長全体に対して 約 $40 \%$ を占有し，高い線形性を広範囲で確保することが困 難であることもわかった。

\section{2 動特性}

動特性試験結果をまとめる。発生流量は平均流量 $8.3 \times 10^{-4}$ $\left[\mathrm{m}^{3} / \mathrm{s}\right]$, 振幅流量 $5.0 \times 10^{-4}\left[\mathrm{~m}^{3} / \mathrm{s}\right]$ とし, 周波数 $10[\mathrm{~Hz}]$ の 振動流の測定結果を Fig. 7 に示す。なお，図中の破線は非 定常流量発生装置より発生した基準流量を示し，実線が層流 型流量計による測定結果を示している。この結果，本層流型 流量計は基準流量と非常に良い一致が見られ，十分精度よく 測定可能であることが確認できた。つぎに，周波数 $50[\mathrm{~Hz}]$ の測定結果を Fig. 8 に $80[\mathrm{~Hz}]$ の測定結果を Fig. 9 に示 す.この結果， $50[\mathrm{~Hz}]$ まで流量ゲインに違いは確認できな かった，位相に関しては， $50[\mathrm{~Hz}] て ゙ ~ 15\left[^{\circ}\right]$ の位相進みとなっ

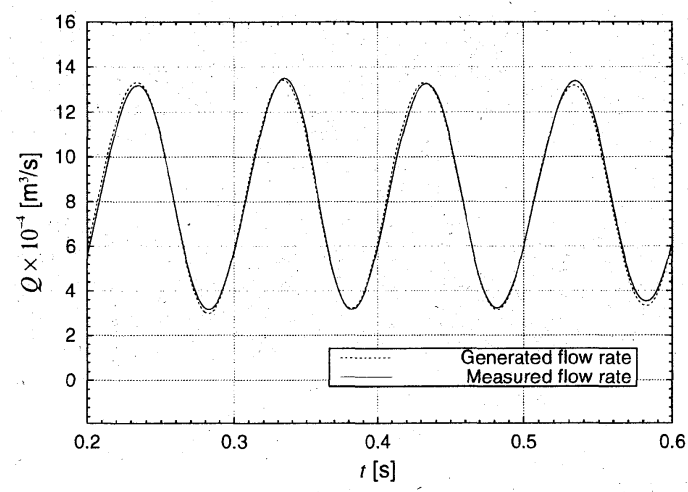

Fig. 7 Experimental results of oscillatory flow at $10[\mathrm{~Hz}]$

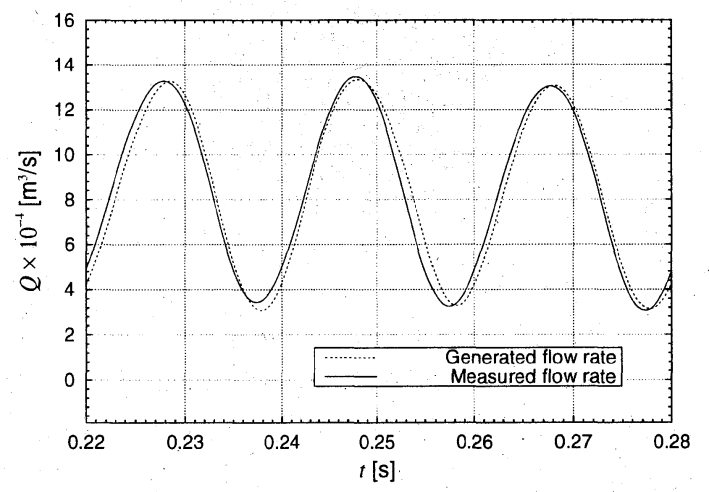

Fig. 8 Experimental results of oscillatory flow at $50[\mathrm{~Hz}]$

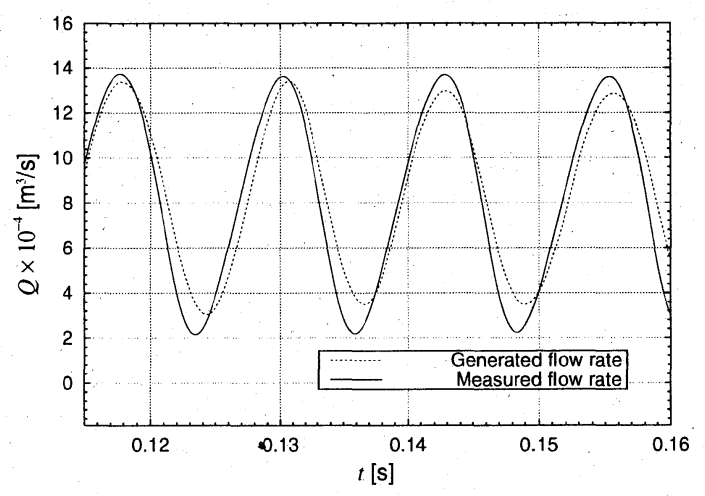

Fig. 9 Experimental results of oscillatory flow at $80[\mathrm{~Hz}]$

た，さらに周波数を高くすると，基準流量よりも測定結果は 大きな流量ゲインを示した，また位相は，徐々に進みの度合 いを強める結果となった。そのほか, Fig. 9 の 80[Hz] の振 動流では，基準流量に対して測定結果の流量波形谷部で測定 值がより小さくなる結果を確認した。この要因として，高周 波時における流体の慣性の影響ではないかと考えられる.

以上の結果をまとめ, 本研究で製作した層流型流量計の 周波数応答特性をボード線図として Fig. 10 に示す. 図中の ○印は測定結果，実線は (17) 式より算出した理論值を示す。 この結果より，層流型流量計はナビエ・ストークス方程式の 解析結果と同じく位相進みとなることが確認できた。また， 


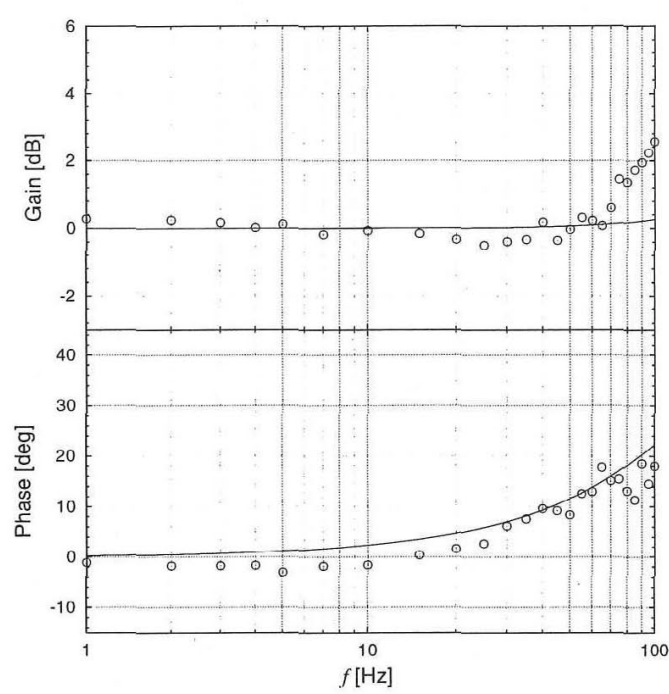

Fig. 10 Bode diagram of laminar flow meter

$50[\mathrm{~Hz}]$ までの振動流の測定結果と理論解析結果はほぼ一致 していることもわかった。しかしながら，70[Hz] 以上では， 理論值と比較してゲインが極端に大きくなる傾向となった。 この要因としては，高周波域での圧力センサの動特性の信頼 性が補償されないことや, 理論展開において平均流速を与え た䛊差および流体の慣性による影響などが考えられる。な お，位相については理論值とほほ一致することを確認した。

\section{6. 結言}

本論文では，高速応答性を有する層流型流量計の設計・製 作を行ない，その動特性評価を実験および理論の両面から明 らかにした。まず，静特性で高い線形性を補償し，動特性試 験結果から，本層流型流量計は $50[\mathrm{~Hz}]$ までの振動流を十分 測定でき, 半導体チップの着座確認などへ有効であることを 確認した。また，ナビエ・ストークス方程式を用いた解析と ウォーマスリイー数による検討から, 周波数が上昇するにつ れてゲインが大きくなり，位相進みとなることも確認した． 今後の課題としては, 加圧下での層流型流量計の特性を明ら かにする点や高周波域のグインに拈ける理論と実験結果の 違いに関する検討が挙げられる，おわりに，本研究に数多く のご助言をいたたいた小宮勤一先生，製作に協力いただいた 高山清隆氏に深謝する。

\section{参考 文 献}

1）小宮勤一ほか：流量計測ハンドブック，日刊工業新聞社 (1969)

2) J.R. Womersley: Method for the calculation of velocity, rate of flow and viscous drag in arteries when the pressure gradient is known, J. Physiol., 127, 553/563 (1955)

3 ) Shigeo Uchida: The pulsating viscous flow superposed on the steady laminar motion of incompressible fluid in a circular pipe, Z. Angew. Math. Phys., 7, 403/422 (1956)

4) C.R. Stone and S.D. Wright: Non-linear and unsteady flow analysis of flow in a viscous flowmeter, Trans. Inst. MC. 16-3, 128/141 (1994)
5）川合一郎ほか：層流形流量計による間欠気流の測定, 日本機械 学会論文集，38-306，295/302 (1972)

6) Kenji Kawashima and Toshiharu Kagawa: Unsteady flow generator for gases using isothermal chamber, Measurement, 33, 333/340 (2003)

7）飯塚幸三監修：ISO 国際文書「計測における不確かさの表現ガ イド」, 日本規格協会 (1996)

8）横田眞一ほか：円管内助走区間における振動流（第 2 報 近似 解析と非定常粘性抵抗係数), 油圧と空気圧, 11-2, 107/114 (1979)

9）北川能ほか：空気任管路の過渡応答の特性曲線法による高速高 精度計算法, 計測自動制御学会論文集, 20-7, 648/653 (1984)

10）香川利春ほか：特性曲線法を用いた空気圧管路容量系の過渡応 答解析, 計測自動制御学会論文集, 20-11，1014/1018 (1984)

11）日本機械学会編：機械工学便覧 基礎編 A5 流体工学 (1986)

12) Tong Zhao, et al.: A Real Time Method of Measuring Unsteady Flow Rate and Velocity Employing Differential Pressure in a Pipe, JSME Int. J., 30-260, 263/270 (1987)

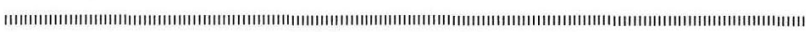

$$
\text { [著者紹介] }
$$

\section{舩 木 達 也（正会員）}

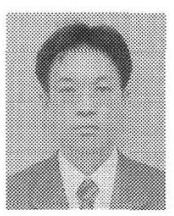

1998 年東京都立科学技術大学機械システム工 学科卒業. 2000 年東京工業大学大学院精密機械 システム専攻修士課程修了. 2002 年東京工業大 学大学院精密機械システム専攻博士後期課程中退. 同.年東京工業大学精密工学研究所助手となり, 現 在に至る。流体計測制御に関する研究に従事. 日 本機械学会, 日本フルードパワーシステム学会な どの会員.

\section{川嶋 健 嗣 (正会員)}

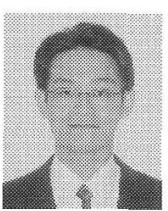

1992 年東京工業大学制御工学科卒業. 1997 年 同大学大学院理工学研究科制御工学専攻博士課程 修了. 同年束京都立工業高等専門学校機械工学科 助手, 2000 年東京工業大学精密工学研究所助教授 となり，現在に至る、流体計測制御，ロボット工 学に関する研究に従事 (博士 (工学)). 日本機械学 会, 日本フルードパワーシステム学会などの会員.

\section{香 川利春（正会員）}

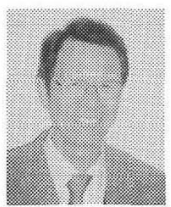

1974 年東京工業大学制御工学科卒業. 同年北 辰電機製作所入社, 1976 年東京工業大学工学部制 御システム工学科助手，同講師，同助教授を経て， 現在同大学精密工学研究所教授. 流体制御システテ 么, 流体計測, 生体計測に関する研究に従事 (工 学博士). 計測自動制御学会評議員, 日本フルー ドパワーシステム学会理事, 日本機械学会などの 会員.

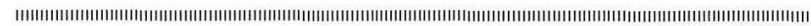

